\title{
Relation between lung asbestos fibre burden and exposure indices based on job history
}

\author{
Ken Takahashi, Bruce W Case, André Dufresne, Richard Fraser, Toshiaki Higashi, \\ Jack Siemiatycki
}

Institute of Industrial Ecological Sciences, University of

Occupational and

Environmental

Health, Kitakyushu, Japan

K Takahashi

T Higashi

Department of

Epidemiology and

Center for

Environmental

Epidemiology,

Graduate School of

Public Health,

University of

Pittsburgh,

Pittsburgh, PA, USA

K Takahashi

B W Case

Department of

Pathology, McGill

University, Montréal,

Canada

B W Case

$R$ Fraser

School of

Occupational Health,

McGill University,

Montréal, Canada

B W Case

A Dufresne

Department of

Epidemiology,

Institute Armand-

Frappier, Laval,

Canada

J Siemiatycki

Correspondence to:

Ken Takahashi, MD

Ken Taktment of

Department of

Envidemiology, Institute of

Industrial Ecological

Sciences, University of

Occupational and

Environmental Health,

Orio, Yahatanishiku,

Kitakyushu City 807 , Japan.

Accepted for publication

7 March 1994

\section{Abstract}

Lung asbestos burden was compared with exposure indices derived from job history interviews in 42 male subjects originating from the Montréal Case-Control Study project, 12 of whom had documented asbestos exposed job histories. Job interview data consisting of a chronological timetable of job histories were translated into detailed exposure indices by an expert group of hygienists and chemists. Total and individual asbestos fibre type concentrations were quantified by transmission electron microscopy with fibre identification by energy dispersive $x$ ray spectrometry after deparaffinisation of tissue blocks and low temperature plasma ashing. Geometric mean or median asbestos content was higher in subjects with an asbestos exposed job history than those without for retained dose of amosite, total commercial amphiboles, and total asbestos fibre. Except for crocidolite fibre diameter, which was significantly less in the lungs of exposed workers, no consistent differences were found in measurements of fibre dimension for any fibre type. Subgroups of subjects exposed to silica, metals, or smokers and non-smokers without significant occupational exposure showed varying patterns of lung asbestos fibre type deficit compared with the asbestos exposed subgroup. There was an overall trend for higher lung asbestos content proportional to higher exposure indices for asbestos representing concentration, frequency, and reliability. These exposure indices as well as duration of exposure (in years) were independent predictors of total asbestos content in regression analyses when combined in a model with age. Stepwise regression indicated that exposure concentration was the most important variable, explaining $32 \%$ of the total variation in total asbestos content. Smoking, whether expressed in ever or never smoked dichotomy or in smokedyears, had no relation to lung asbestos content in this model.

(Occup Environ Med 1994;51:461-469)

The assessment of dose-response relations is a central theme in many occupational epidemiology studies. But because dose is difficult to measure in practice, estimates of exposure are substituted for dose based on the assumption that the estimate of exposure is a justifiable surrogate for dose. Estimates of exposure are usually obtained from job history interviews and often take the form of ordinally ranked exposure indices.

"Burden" is an unfortunate term which can be best defined as the dose at a point in time ${ }^{1}$ and is thus more quantifiable than dose. A better term for lung fibre burden is thus lung retained fibre dose, and such studies ${ }^{2-12}$ are examples of the use of internal dose biomarkers of exposure in occupational epidemiology. ${ }^{13}$ Advancements in electron microscopic techniques have contributed to the estimation of retained fibre in lung tissue. Recently a systematic method to assess both fibrous and non-fibrous inorganic particles has been developed by Dufresne et al. ${ }^{2}$ It is a comprehensive method designed to elicit the total profile of lung retained dose for all identifiable inorganic material. The method was applied to subgroups derived from a large series of patients with cancer from the Montréal CaseControl Study ${ }^{14-17}$ project (Montréal project), comparing the total lung particulate profile with extensive job exposure histories, a large number of whom went on to death with necropsy examination or to surgical intervention (pneumonectomy or lung lobectomy). The Montréal project includes comprehensive information on age, smoking state, exposure duration (years exposed), exposure intensity (concentration in the workplace by expert judgment), exposure frequency during the work day (frequency), and confidence with which history of asbestos exposure could be expressed (reliability). The present analysis extends this study to specifically consider the relation between total and individual lung asbestos fibre concentration and type and these ordinal exposure indices obtained from the job history interviews.

\section{Methods}

SUBJECTS

Subjects were men with cancer at various sites, and originated from the Montréal project, a population based case-control monitoring system initiated by Siemiatycki et al in 1979. ${ }^{14-17}$ In the project, researchers gave in depth interviews and/or questionnaires for job and exposure histories to over 1500 men in 19 Montréal hospitals. As an ongoing component of the project, two pathologists searched the necropsy files of six participating Montréal hospitals to identify all matches to the 
projects's membership file for last name, first name, date of birth, pathology number at original diagnosis, and medical care insurance number. ${ }^{3}$

From about 150 matches, 42 subjects were identified. These men were chosen to represent subgroups with, to the extent possible, significant, non-overlapping job exposures to asbestos $(n=12)$, silica $(n=8)$, metals $(n=$ 10), cigarette smokers without significant occupational exposures to any of these ( $n=$ 6 ), and non-smokers similarly without significant occupational exposure $(n=6)$. Complete exclusion of overlapping exposures was impossible: for example, two men with exposure to asbestos also had exposure to silica and three other men with exposure to silica (but without asbestos exposure) also had exposure to metals. The mean age of the subjects was 61 (range 42-76) at the time when lung tissue was obtained from necropsy ( 37 subjects) or from pneumonectomy or lobectomy (five subjects). Two of the 12 subjects having any asbestos exposed job history at the time of interview who also had exposure to silica in the workplace were included as asbestos exposed rather than exposed to silica in this study. Twelve subjects held a total of 16 asbestos exposed job histories and 30 subjects had no lifetime asbestos exposed job history as judged by the industrial hygiene team.

\section{EVALUATION OF EXPOSURE}

An expert group of hygienists and chemists evaluated the job histories and coded exposure indices for each job with three priority variables for asbestos related and other exposures. Firstly, the concentration of exposure was rated as zero (none), 1 (slight), 2 (moderate), or 3 (extensive). Secondly, the frequency of exposure during a normal workweek was rated as zero (never), 1 (less than $5 \%$ of time), 2 (from $5 \%$ to $30 \%$ ), or 3 (more than $30 \%$ ). Thirdly, the hygiene teams' reliability judgment of the exposure estimation was coded as zero (none), 1 (possible), 2 (probable), or 3 (certain). These procedures have been shown to have good between rater agreement in previous work. ${ }^{1418}$ For the present study, duration of employment in asbestos exposed industries was added as a fourth exposure index by summing years worked in such industries. The original hygiene data distinguished suspected exposure to chrysotile and/or commercial amphiboles, although the amphiboles could not be subgrouped into crocidolite and amosite by interviews. Lifetime asbestos exposed job history by definition, is not distinguished by type of fibre. Thus each exposure index for lifetime asbestos exposed job history was represented by the higher rating value of the exposure to chrysotile or commercial amphiboles. As well as asbestos exposed job history, smoking histories were extracted from interview data both as ever or never smoked dichotomy and smoked-years.

ANALYSIS OF LUNG TISSUE FIBRE

Tissue samples were processed according to a modification of the technique described previously by Case and Sébastien ${ }^{4}$ and by Dufresne et al. ${ }^{2}$ Briefly, the protocol involves removal of paraffin from tissue by immersion in xylene heated to $70^{\circ} \mathrm{C}$. Xylene is removed from deparaffinised lung by filtration through a cellulose filter having pore size $0.45 \mu \mathrm{m}$ and the residual lung tissue, together with a portion of the filter used in xylene removal, is weighed and treated in a low temperature plasma asher overnight. The residual is filtered through polycarbonate filters $(0.2 \mu \mathrm{m}$ pore size) and mounted on No 200 copper mesh grids with a carbon replica technique as described previously. Deparaffinisation is followed by counting and sizing of particles and fibres by transmission electron microscopy combined with identification of particle chemistry from energy dispersive $x$ ray spectrometry. Preparation and analytical protocols were validated so that a representative number of particles could be counted and reasonably characterised from their morphology and their chemical composition. ${ }^{23}$ The theoretical detection limit for fibrous particles including asbestos in this study was 0.07 fibres per $\mu \mathrm{g}$ $(0.07 \mathrm{f} / \mu \mathrm{g}$ or $70000 \mathrm{f} / \mathrm{g}$; longer than $3 \mu \mathrm{m}$; aspect ratio greater than 3:1) dry lung. Total fibre count of all asbestos fibres was obtained for the analysis, as well as fibre type and dimension. Fibres were typed from morphology and energy dispersive $x$ ray spectrometry spectra. Length, diameter, and aspect ratio were determined through direct on screen measurements relative to concentric circles of 1 $\mu \mathrm{m}$ and $5 \mu \mathrm{m}$ as in previous work.

\section{STATISTICAL ANALYSIS}

Two separate methods were applied to determine the relation between occupational history data and lung fibre analysis. Firstly, the subjects with a positive asbestos exposured job history $(n=12)$ were compared with subjects in each of the other exposure subgroups and to the total 30 subjects not exposed to asbestos (negative asbestos exposured job history) in a descriptive analysis. This had the advantage of allowing detailed fibre type analyses in the subgroups. Median and geometric mean results for chrysotile, amosite, crocidolite, tremolite, total commercial amphibole, total chrysotile and tremolite, and total lung asbestos fibre were compared by the Mann-Whitney and two sample $t$ tests (with separate estimates of variance) respectively, in the MINITAB statistical software (version 7). For this analysis, fibre dimensions are also described for each fibre type for the asbestos exposed subgroup $v$ all others. Geometric mean within subject fibre dimensions (length, diameter, and aspect ratio) were first calculated and these values were used in comparisons of median between subject fibre dimension categories with the Mann-Whitney procedure.

In the second group of comparisons, multiple linear regression analyses were performed with SAS statistical software (version 6.04). This allowed for separate inclusion of each of the four industrial hygiene asbestos exposure variables (exposure duration in 
Table 1 Geometric mean (SD) of lung asbestos content (flug dry lung) S for 12 subjects with asbestos exposed job history (AEH) $v 30$ subjects without $A E H$ and four exposure subgroups

\begin{tabular}{|c|c|c|c|c|c|c|c|}
\hline \multirow[b]{2}{*}{ fob history } & \multicolumn{7}{|l|}{ Fibre type } \\
\hline & Amosite & Crocidolite & Amphiboles\| & Tremolite & Chrysotile & $\begin{array}{l}\text { Chrysotile/ } \\
\text { tremoliteף }\end{array}$ & Total asbestos \\
\hline $\begin{array}{l}\text { With AEH }(n=12) \\
\text { Without AEH }(n=30)+t \\
\text { Exposed to silica }(n=8) \\
\text { Exposed to metals }(n=10) \\
\text { Smokers without exposure\# }(n=6) \\
\text { Non-smokers without exposure }(n=6)\end{array}$ & $\begin{array}{l}0.09(9 \cdot 3) \\
0.03(2 \cdot 7)^{\star} \\
0.02(1 \cdot 9)^{\star} \\
0.04(3 \cdot 8) \\
0.02(1 \cdot 8) \dagger \\
0.03(2 \cdot 8)\end{array}$ & $\begin{array}{l}0.04(4 \cdot 2) \\
0.02(1 \cdot 7) \\
0 \cdot 03(2 \cdot 3) \\
0 \cdot 02(1 \cdot 6) \\
\text { ND } \\
\text { ND }\end{array}$ & $\begin{array}{l}0.16(10.0) \\
0.03(2.9) \dagger \\
0.03(2.8) \dagger \\
0.04(3.8)^{\star} \\
0.02(3.1) \dagger \\
0.03(2.9) \dagger\end{array}$ & $\begin{array}{l}0.03(3 \cdot 0) \\
0.04(2 \cdot 9) \\
0.05(3 \cdot 1) \\
0.03(2 \cdot 2) \\
0.07(3.4) \\
0.03(3 \cdot 3)\end{array}$ & $\begin{array}{l}0.04(4.5) \\
0.03(2.7) \\
0.02(1.8) \\
0.03(3.0) \\
0.06(3.0) \\
0.03(3.0)\end{array}$ & $\begin{array}{l}0.06(5.2) \\
0.06(3.4) \\
0.06(3.4) \\
0.05(3.3) \\
0.14(3.1) \\
0.05(3.8)\end{array}$ & $\begin{array}{l}0.28(10.1) \\
0.09(3.5) \\
0.08(3.3) \\
0.09(3.8) \\
0.15(3.0) \\
0.06(4.3)\end{array}$ \\
\hline
\end{tabular}

${ }^{\star} \mathrm{p}<0.1 ;$ tp $<0.05 v 12$ subjects with AEH.

$\neq$ Not detected.

All fibres having length greater than $3 \mu \mathrm{m}$, aspect ratio greater than 3:1.

All commercial amphiboles (crocidolite and amosite only).

IAll tremolite plus all chrysotile fibre, including cleavage fragments meeting the fibre definition in $\S$.

HAll men in the four exposure subgroups (silica, metals, unexposed smokers, unexposed non-smokers) combined.

\#No exposure to particulates recorded by industrial hygiene assessment of detailed job history.

years, concentration, frequency, and reliability in exposure coding) as well as age at necropsy or pneumonectomy (as proxy for possible effects of fibre clearance) and smoking. Smoking was evaluated both as ever or never smoked dichotomy and smoked-years in separate analyses (two men with positive exposure history for asbestos had smoked but lacked details on smoked-years and had to be excluded from this model). For these analyses, duration of exposure was calculated as the sum of years worked in all jobs with exposure to any type of asbestos, and higher rating values were chosen to represent lifetime asbestos exposed job history if different values were coded for separate asbestos exposure histories. Stepwise linear regression with all exposure variables, age, and smoking state was then applied to determine the multivariate model with the most independent predictive value. Models were used to predict total lung fibre asbestos content (dependent variable) only, with exposure variables, age at necropsy or pneumonectomy, and smoking state as independent variables.

\section{Results}

Mean duration of exposure among the 12 subjects with asbestos exposed job history was 23 years: the range was four to 46 years. In total lung asbestos fibre analysis, 30 of the 42 subjects $(71 \%)$ had detectable asbestos content with a range of $0.07-41.6 \mathrm{f} / \mu \mathrm{g}$. The geometric mean of total asbestos content for all
42 subjects was $0 \cdot 12 \mathrm{f} / \mu \mathrm{g}$. Geometric mean total asbestos content (table 1) in those exposed was $0.28 \mathrm{f} / \mu \mathrm{g}$ (longer than $3 \mu \mathrm{m}$, aspect ratio >3:1), $v 0.09 \mathrm{f} / \mu \mathrm{g}$ in the unexposed 30 subjects (NS). In the comparison of individual fibre types between subjects with asbestos exposed job history and without, significant excesses were recorded for total commercial amphiboles $(0.16 \mathrm{f} / \mu \mathrm{g} v$ $0.03 \mathrm{f} / \mu \mathrm{g} ; \mathrm{p}<0.05$ ), but not for chrysotile or for any other individual fibre type, although the comparison for geometric mean amosite approached significance $(0.09 \mathrm{f} / \mu \mathrm{g} v 0.03$ $\mathrm{f} / \mu \mathrm{g} ; \mathrm{p}=0.08$ ). Total commercial amphiboles were independently in significant excess in the lungs of subjects with asbestos exposed job history $v$ those exposed to silica and to the subgroups of smokers and non-smokers, and the excess approached significance $(p<0.1)$ in those primarily exposed to metals. The subgroup consisting of smokers who were white collar workers without occupational exposures showed an unusual fibre type retention pattern with geometric mean contents of both chrysotile and tremolite increased (NS) and with a significant deficit of amosite $(0.02$ $\mathrm{f} / \mu \mathrm{g} v 0.09 \mathrm{f} / \mu \mathrm{g}$ in the asbestos exposed subgroup; $\mathrm{p}<0.05$ ).

Comparisons of median fibre concentration (table 2) for asbestos exposed $v$ unexposed subjects and across subgroups showed a similar pattern, except for a significant excess of amosite (median $0.09 \mathrm{f} / \mu \mathrm{g} v 0 \mathrm{f} / \mu \mathrm{g} ; \mathrm{p}<0.05$ ) in asbestos exposed $v$ unexposed subjects. The proportion of subjects with greater than

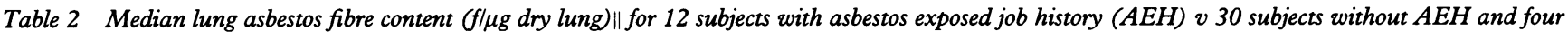
exposure subgroups

\begin{tabular}{|c|c|c|c|c|c|c|c|}
\hline \multirow[b]{2}{*}{ fob history } & \multicolumn{7}{|c|}{ Fibre type } \\
\hline & Amosite & Crocidolite & Amphiboles & Tremolite & Chrysotile & $\begin{array}{l}\text { Chrysotile/ } \\
\text { tremoliteft }\end{array}$ & Total asbestos \\
\hline $\begin{array}{l}\text { With AEH }(n=12) \\
\text { Without AEH }(n=30)+† \\
\text { Exposed to silica }(n=8) \\
\text { Exposed to metals }(n=10) \\
\text { Smokers without exposure } \$(n=6) \\
\text { Non-smokers without exposure } \$(n=6)\end{array}$ & $\begin{array}{l}0 \cdot 09 \\
0+ \\
0^{\star} \\
0 \\
0^{\star} \\
0\end{array}$ & $\begin{array}{l}0 \\
0 \\
0 \\
0 \\
\text { NDS } \\
\text { NDS }\end{array}$ & $\begin{array}{l}0 \cdot 12 \\
0 \ddagger \\
0^{\star} \\
0 \\
0+ \\
0^{\star}\end{array}$ & $\begin{array}{l}0 \\
0 \\
0 \cdot 06 \\
0 \\
0 \cdot 11 \\
0\end{array}$ & $\begin{array}{l}0 \\
0 \\
0 \\
0 \\
0 \cdot 08 \\
0\end{array}$ & $\begin{array}{l}0.07 \\
0 \\
0.07 \\
0.04 \\
0.11 \\
0.04\end{array}$ & $\begin{array}{l}0 \cdot 27 \\
0 \cdot 08 \\
0 \cdot 07 \\
0 \cdot 08 \\
0 \cdot 21 \\
0.04\end{array}$ \\
\hline
\end{tabular}

${ }^{\star} \mathrm{p}<0.1 ; \mathrm{tp}<0.05 ; \mathrm{fp}<0.01$ v 12 subjects with AEH

$\mathrm{p}<0 \cdot 1 ; \mathrm{tp}<0$
Not detected.

All fibres having length greater than $3 \mu \mathrm{m}$, aspect ratio greater than 3:1.

All fibres having length greater than $3 \mu \mathrm{m}$, aspect ratio grea

IAll commercial amphiboles (crocidolite and amosite only).

HAll tremolite plus all chrysotile fibre, including cleavage fragments meeting the fibre definition in $\|$.

\#INo exposure to particulates recorded by industrial hygiene assessment of detailed job history. 
Table 3 Characteristics of six men with high lung content of total asbestos

\begin{tabular}{|c|c|c|c|c|c|c|}
\hline \multirow[b]{2}{*}{$A g e^{\star}$} & \multirow[b]{2}{*}{ Asbestos job historyt } & \multicolumn{3}{|c|}{ Asbestos exposure rating $\ddagger$} & \multirow{2}{*}{$\begin{array}{l}\text { Asbestos lung content } \\
\text { by fibre type } \\
\text { (flug dry lung) }\end{array}$} & \multirow[b]{2}{*}{ Pathology } \\
\hline & & Concentration & Frequency & Reliability & & \\
\hline 56 & $\begin{array}{l}\text { (1) Asbestos transformation plant: } 20 \text { years }{ }^{1} \\
\text { (2) Plumber: } 10 \text { years }^{2}\end{array}$ & $\begin{array}{l}3 \\
2\end{array}$ & $\begin{array}{l}3 \\
3\end{array}$ & $\begin{array}{l}3 \\
3\end{array}$ & Amosite $41 \cdot 6$ & $\begin{array}{l}\text { Gastrointestinal cancer } \\
\text { (asbestos bodies seen) }\end{array}$ \\
\hline 54 & $\begin{array}{l}\text { (1) Asbestos transformation plant: } 1 \text { year }^{3} \\
\text { (2) Welder: } 11 \text { years }^{4}\end{array}$ & 3 & $\begin{array}{l}1 \\
2\end{array}$ & $\begin{array}{l}3 \\
2\end{array}$ & Crocidolite 1.8 & $\begin{array}{l}\text { Asbestosis } \\
\text { (pleural plaques) }\end{array}$ \\
\hline 71 & $\begin{array}{l}\text { (1) Construction: } 3 \text { years } \\
\text { (2) Construction: } 13 \text { years }^{6}\end{array}$ & 1 & $\begin{array}{l}1 \\
1\end{array}$ & $\begin{array}{l}2 \\
2\end{array}$ & $\begin{array}{l}\text { Chrysotile } 0.98 \\
\text { Tremolite } 0.14 \\
\text { Amosite } 0.07\end{array}$ & Lung cancer \\
\hline 64 & Pipe fitter in oil refinery: 30 years ${ }^{7}$ & 2 & 2 & 3 & $\begin{array}{l}\text { Amosite } 0.56 \\
\text { Crocidolite } 0.07 \\
\text { Chrysotile } 0.14 \\
\text { Tremolite } 0.07\end{array}$ & Lung cancer \\
\hline 53 & Electrician: 21 years $^{8}$ & 1 & 1 & 2 & $\begin{array}{l}\text { Chrysotile } 0.42 \\
\text { Tremolite } 0 \cdot 14 \\
\text { Amosite } 0 \cdot 21\end{array}$ & Sezary syndrome \\
\hline 42 & None identified (welding 22 years) & 0 & 0 & 0 & $\begin{array}{l}\text { Amosite } 0.54 \\
\text { Chrysotile } 0.08 \\
\text { Tremolite } 0.08\end{array}$ & Gastrointestinal cancer \\
\hline
\end{tabular}

*Age at necropsy or pneumonectomy.

†For each asbestos exposed job history, exposure coding values (concentration, frequency, reliability) by fibre type are as follows: ${ }^{1}$ chrysotile $(3,3,3)$, commercial amphiboles $(2,3,3) ;{ }^{2}$ chrysotile $(2,3,3)$, commercial amphiboles $(2,3,2) ;{ }^{3}$ chrysotile $(3,1,3)$, commercial amphiboles $(2,1,2)$; ${ }^{4} \mathrm{chrysotile}(1,2,2)$, commercial amphiboles $(0,0,0)$; ${ }^{5}$ chrysotile $(1,1,2)$, commercial amphiboles $(0,0,0)$; ${ }^{6}$ chrysotile: $(1,1,2)$, commercial amphiboles $(0,0,0)$; ${ }^{7}$ chrysotile $(2,2,3)$, commercial amphiboles $(0,0), 0,0)$

$\ddagger$ See methods for definitions of exposure variables and coding values elicited by job history.

$0 \cdot 1 \mathrm{f} / \mu \mathrm{g}$ asbestos content for those with and without an asbestos exposed job history, were $67 \%(8 / 12)$ and $47 \%(14 / 30)$, respectively (NS). In three of the 12 subjects with an asbestos exposed job history, the generally accepted level of unequivocal occupational exposure ( $1 \mathrm{f} / \mu \mathrm{g}$ dry lung or 1 million $\mathrm{f} / \mathrm{g}$ ) was exceeded (table 3 ). Of the three, two had exposure history as labourers in an asbestos plant and one as a construction worker. Three additional subjects had asbestos fibre counts exceeding $0.5 \mathrm{f} / \mu \mathrm{g}$. Five of the six men having significant asbestos exposure by this criterion were identified as such by the industrial hygiene team: only one subject had a lung content exceeding $0.5 \mathrm{f} / \mu \mathrm{g}$ but had a negative occupational history, in this case as an acetylene welder in a metals processing facility. Table 4 shows the results obtained for lung asbestos fibre analysis in the seven men having a positive exposure history but lower levels of intrapulmonary asbestos. It should be noted that the first of these corresponded to the eighth highest value in the study, and all but two others had only low level exposures as evaluated by industrial hygiene measures.

Table 5 shows the geometric mean and SD of total lung asbestos content by three exposure indices for the 12 subjects with asbestos exposed job history $v$ the 30 without. For all three indices of exposure, the unexposed subjects had the lowest and the most extensive exposure subgroup the highest geometric mean of total asbestos. The two subjects with the highest lung content were in the highest category for concentration and reliability, and in the second highest category for frequency in one subject. The overall trend of higher asbestos lung content corresponding with higher exposure index in the respective exposure variables is none the less most apparent in frequency. There was considerable overlap among values for each exposure variable between the lowest two categories of exposure and lack of exposure, showing a failure of lung content to discriminate exposure at these lower levels of exposure indices.

The proportion of smokers (of any kind of tobacco) among those with and without asbestos exposed job history was $100 \%$ $(12 / 12)$ and $73 \%(22 / 30)$, respectively. Lung asbestos content was again compared between three subgroups by taking smoking history into consideration. The geometric means of lung asbestos content for subjects with no asbestos exposed job history and no smoking history $(n=8)$, subjects with no asbestos exposed job history but with positive smoking

Table 4 Characteristics of seven men with an asbestos exposed job history (AEH) and lower lung content of total asbestos

\begin{tabular}{|c|c|c|c|c|c|c|}
\hline \multirow[b]{2}{*}{$A g e^{*}$} & \multirow[b]{2}{*}{ Asbestos job history† } & \multicolumn{3}{|c|}{ Asbestos exposure rating $\ddagger$} & \multirow{2}{*}{$\begin{array}{l}\text { Asbestos lung content } \\
\text { by fibre type } \\
\text { (flug dry lung) }\end{array}$} & \multirow[b]{2}{*}{ Pathology } \\
\hline & & Concentration & Frequency & Reliability & & \\
\hline 56 & $\begin{array}{l}\text { (1) Electrician in construction industry: } 9 \text { years }{ }^{1} \\
\text { (2) Repairer of electrical instruments: } 22 \text { years }\end{array}$ & 1 & 2 & 3 & $\begin{array}{l}\text { Tremolite } 0.25 \\
\text { Amosite } 0.08 \\
\text { Crocidolite } 0.08\end{array}$ & Lung cancer \\
\hline 67 & Maintenance worker on loading dock: 46 years $^{3}$ & 2 & 2 & 3 & Crocidolite 0.09 & Lung cancer \\
\hline 70 & Furnace operator: 13 years ${ }^{4}$ & 1 & 2 & 2 & $\begin{array}{l}\text { Chrysotile } 0 \cdot 10 \\
\text { Amosite } 0.03\end{array}$ & Gastrointestinal cancer \\
\hline $\begin{array}{l}59 \\
56 \\
70 \\
70\end{array}$ & $\begin{array}{l}\text { Engineer and furnace operator: } 32 \text { years } \\
\text { Ship furnace operator: } 4 \text { years } \\
\text { Salesman of used auto parts: } 6 \text { years } \\
{\text { Mechanic: } 34 \text { years }^{8}}^{7}\end{array}$ & $\begin{array}{l}1 \\
2 \\
1 \\
1\end{array}$ & $\begin{array}{l}2 \\
1 \\
1 \\
2\end{array}$ & $\begin{array}{l}2 \\
2 \\
2 \\
2\end{array}$ & $\begin{array}{l}\text { Amosite } 0.07 \\
\text { None detected } \\
\text { None detected } \\
\text { None detected }\end{array}$ & $\begin{array}{l}\text { Lung cancer } \\
\text { Lung cancer } \\
\text { Lung cancer } \\
\text { Gastrointestinal cancer }\end{array}$ \\
\hline
\end{tabular}

^Age at autopsy or pneumonectomy.

†For each asbestos exposed job history, exposure coding values (concentration, frequency, reliability) by fibre type are as follows: 'chrysotile (1,1,2), commercial amphiboles $(0,0,0) ;{ }^{2}$ chrysotile $(1,2,3)$, commercial amphiboles $(1,2,2) ;{ }^{3}$ chrysotile $(2,2,3)$, commercial amphiboles $(2,2,3) ;{ }^{4} \mathrm{chrys}$ ctile $(1,2,2)$, commercial amphiboles $(1,2,2)$; 'chrysotile $(1,2,2)$, commercial amphiboles $(1,2,2)$; ${ }^{\circ}$ chrysotile $(2,1,2)$, commercial amphiboles $(2,1,2) ;{ }^{7}$ chrysotile $(1,1,2)$, commercia amphiboles $(0,0,0) ;{ }^{8}$ chrysotile $(1,2,2)$, commercial amphiboles $(0,0,0)$ 
Table 5 Geometric mean (SD) of total lung asbestos content (f/ $\mu \mathrm{g}$ dry lung) according to asbestos exposed job history $(A E H)$ and exposure indices

\begin{tabular}{|c|c|c|c|c|c|}
\hline $\begin{array}{l}\text { Asbestos } \\
\text { exposed job } \\
\text { history } \\
(A E H)\end{array}$ & $\begin{array}{l}3 \text { point scale } \\
\text { code for } \\
\text { exposure } \\
\text { variables }\end{array}$ & & $\begin{array}{l}\text { Concentration } \\
\text { index } \star\end{array}$ & $\begin{array}{l}\text { Frequency } \\
\text { index }\end{array}$ & $\begin{array}{l}\text { Reliability } \\
\text { index }\end{array}$ \\
\hline \multirow[t]{2}{*}{$\begin{array}{l}\text { Without AEH } \\
\text { With AEH }\end{array}$} & $(0) \dagger$ & $\begin{array}{l}0.09(3.5)(\mathrm{n}=30) \\
0.28(10.1)(\mathrm{n}=12)\end{array}$ & & & \\
\hline & $\begin{array}{l}1 \\
2 \\
3\end{array}$ & & $\begin{array}{l}0.14(5 \cdot 6)(\mathrm{n}=7) \\
0 \cdot 14(7 \cdot 0)(\mathrm{n}=3) \\
8 \cdot 7(9 \cdot 1)(\mathrm{n}=2)\end{array}$ & 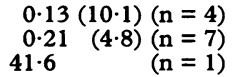 & $\begin{array}{l}\quad(n=0) \\
0.09(6 \cdot 1)(n=7) \\
1.4(8 \cdot 2)(n=5)\end{array}$ \\
\hline
\end{tabular}

* See methods for definitions of exposure variables and coding values elicited by job history.

†No asbestos exposed job history is implicitly coded as 0 .

history ( $n=22)$, and the 12 subjects with a positive asbestos exposed job history (all smokers) were $0.08,0.09$, and $0.28 \mathrm{f} / \mu \mathrm{g}$ respectively.

In multiple regression analyses modelled independently for each of the four exposure variables combined with age and ever/never smoking state (table 6), there were significant relations between total lung asbestos content and exposure duration, concentration, frequency, and reliability. Higher age at necropsy or pneumonectomy predicted significantly lower lung asbestos content for exposure models based on each index, suggesting a significant role for fibre clearance. Smoking state did not significantly contribute to the prediction of asbestos fibre retention for ever or never smoked state. Dropping two subjects with asbestos exposure but without detailed smoking history and using smoked-years instead of ever or never smoked state did not change this conclusion and retained significance for the explanatory value of all four exposure variables and for age (data not shown), but as a subgroup of smokers was chosen for lack of occupational exposure results on smoking should be interpreted with caution. Regression analyses, although significant for all exposure indices, differed in their explanation of lung asbestos content variance from $23 \%$ ( $\mathbf{R}^{2}$ for the model based on exposure duration; $p<0.05)$ to $32 \%\left(R^{2}\right.$ for the model based on exposure concentration; $\mathrm{p}<0.005$ ).

Stepwise linear regression resulted in a two term model that retained only concentration of exposure $(p<0.005)$ and age at necropsy or pneumonectomy $(p<0.05$; negative relation) as independent predictors of lung asbestos content. The full model was explanatory of a total of $32 \%$ of lung content variance $(p<0.001)$. Dropping lung retained amphibole dose data from the results produced chrysotile only regressions that were completely lacking in statistical significance for any relation between chrysotile lung content and chrysotile exposure history, even though some individual values of chrysotile were quite high (table 3 ).

Comparisons of fibre dimensions were generally unrevealing (table 7). Amosite was identified in $67 \%$ (48 fibres in eight subjects) of those with asbestos exposed job history and only $23 \%$ of those without (17 fibres in seven subjects; $p<0.05$ ). Amosite was highly variable in geometric mean within subject length (between 3.6 and $22.0 \mu \mathrm{m}$ ), with no significant differences in fibre length, diameter, or aspect ratio for asbestos exposed (median between subject fibre length $7 \cdot 4 \mu \mathrm{m}$, median diameter $0.20 \mu \mathrm{m}$ and median aspect ratio $33: 1$; $v$ length $9.5 \mu \mathrm{m}$, diameter $0.20 \mu \mathrm{m}$, and aspect ratio $37: 1$ in the unexposed subjects). Crocidolite was identified in the lungs of four asbestos exposed workers (33\%) and two unexposed $(7 \%)$ workers. Eighty eight per cent (29/33) of the crocidolite fibres identified were in the lungs of asbestos exposed workers and median between subject length was greater (6.5 $v 4.8 \mu \mathrm{m}, \mathrm{NS})$, median width narrower $(0.18 v 0.28 \mu \mathrm{m}, \mathrm{p}<0.05)$, and median aspect ratio greater (37:1 $v 27: 1$; NS) than in the two men without such history: crocidolite thus showed the largest dimensional differences between groups. Overall, $79 \%(77 / 98)$ of commercial amphibole fibres were seen in the lungs of $75 \%(9 / 12)$ of men with an asbestos exposed job history.

Table 6 Multiple regression analyses predicting total lung asbestos content $\|$ in all 42 subjects

\begin{tabular}{|c|c|c|c|c|c|}
\hline & \multicolumn{5}{|c|}{ Full model incorporating one of the exposure variables } \\
\hline & $\begin{array}{l}\text { Exposure } \\
\text { Duration (y) }\end{array}$ & $\begin{array}{l}\text { Concentrationtt } \\
\text { index }\end{array}$ & $\begin{array}{l}\text { Frequencytt } \\
\text { index }\end{array}$ & $\begin{array}{l}\text { Reliabilitytt } \\
\text { index }\end{array}$ & Stepwise model \\
\hline $\begin{array}{l}\text { Age (y) } \\
\text { Smoking state\# }\end{array}$ & $\begin{array}{c}-0.03^{\star} \\
0.02\end{array}$ & $\begin{array}{l}-0.03^{\star} \\
-0.03\end{array}$ & $\begin{array}{l}-0.03^{\star} \\
-0.04\end{array}$ & $\begin{array}{l}-0.03^{\star} \\
-0.04\end{array}$ & $-0.03^{\star}$ \\
\hline $\begin{array}{l}\text { Exposure index } \\
\text { Exposure duration (y) } \\
\text { Concentration index } \\
\text { Frequency index } \\
\text { Reliability index } \\
\mathbf{R}^{2} \\
\text { p Value }\end{array}$ & $\begin{array}{l}0.02 \\
- \\
- \\
- \\
0.23 \\
0.0163\end{array}$ & $\begin{array}{l}- \\
0.41 \mathrm{tt} \\
- \\
\overline{0} \\
0.32 \\
0.0021\end{array}$ & $\begin{array}{l}\overline{-} \\
\overline{0.38 \mathrm{Ht}} \\
\overline{0.29} \\
0.0039\end{array}$ & $\begin{array}{l}- \\
- \\
- \\
0.27 t \\
0.28 \\
0.0062\end{array}$ & $\begin{array}{l}\int \\
0.41+t \\
5 \\
0.32 \\
0.0006\end{array}$ \\
\hline
\end{tabular}


Table 7 Sizing data by fibre type for 12 subjects with asbestos exposed job history (AEH) $v 30$ subjects without AEH

\begin{tabular}{|c|c|c|c|c|}
\hline $\begin{array}{l}\text { Fibre type } \\
\text { (total No } \\
\text { of subjects with and } \\
\text { without } A E H \text { ) }\end{array}$ & $\begin{array}{l}\text { No of fibres } \\
\text { identified (No } \\
\text { of subjects in whom } \\
\text { fibres were identified) }\end{array}$ & Length $\ddagger(\mu m)$ & Diameter $\ddagger(\mu m)$ & Aspect ratio $\ddagger$ \\
\hline $\begin{array}{l}\text { Chrysotile } \\
\text { With AEH }(n=12) \\
\text { Without AEH }(n=30)\end{array}$ & $\begin{array}{l}46(15) \\
25(4) \\
21(11)\end{array}$ & $\begin{array}{l}4 \cdot 6 \\
4 \cdot 5\end{array}$ & $\begin{array}{l}0 \cdot 20 \\
0 \cdot 10\end{array}$ & $\begin{array}{l}26: 1 \\
50: 1\end{array}$ \\
\hline $\begin{array}{l}\text { Tremolite } \\
\text { With AEH }(n=12) \\
\text { Without AEH }(n=30)\end{array}$ & $\begin{array}{l}36(18) \\
8(4) \\
28(14)\end{array}$ & $\begin{array}{l}5 \cdot 7 \\
5 \cdot 3\end{array}$ & $\begin{array}{l}0.95 \\
0.50^{\star}\end{array}$ & $\begin{array}{l}6: 1 \\
7: 1\end{array}$ \\
\hline $\begin{array}{l}\text { Amosite } \\
\text { With AEH }(n=12) \\
\text { Without AEH }(n=30)\end{array}$ & $\begin{array}{l}65(15) \\
48(8) \\
17(7)\end{array}$ & $\begin{array}{l}7 \cdot 4 \\
9 \cdot 5\end{array}$ & $\begin{array}{l}0 \cdot 20 \\
0.20\end{array}$ & $\begin{array}{l}33: 1 \\
37: 1\end{array}$ \\
\hline $\begin{array}{l}\text { Crocidolite } \\
\text { With AEH }(\mathrm{n}=12) \\
\text { Without AEH }(\mathrm{n}=30)\end{array}$ & $\begin{array}{r}33(6) \\
29(4) \\
4(2)\end{array}$ & $\begin{array}{l}6 \cdot 5 \\
4 \cdot 8\end{array}$ & $\begin{array}{l}0.18 \\
0.28 \dagger\end{array}$ & $\begin{array}{l}37: 1 \\
27: 1\end{array}$ \\
\hline
\end{tabular}

${ }^{\star} \mathrm{p}<0.1 ; \mathrm{tp}<0.05 v 12$ subjects with AEH.

$\ddagger$ Figures for length, diameter, and aspect ratio are median fibre dimensions between subjects based on geometric mean fibre dimensions within subjects (see methods for details).

Chrysotile ( $n=46$ fibres in 15 subjects) was generally rather short, with no geometric mean within subject fibre length exceeding $11.0 \mu \mathrm{m}$, but diameter was consistently less than $0.2 \mu \mathrm{m}$ leading to very high geometric mean aspect ratios $(>20: 1$ in $80 \% ;>40: 1$ in eight of 15 subjects). Chrysotile was present in the lungs of $33 \%$ of workers and $37 \%$ of the unexposed subjects. Fibre dimensions did not differ significantly between those with an asbestos exposed job history and those unexposed by history (median between subject length $4.6 \mu \mathrm{m}$ in those with an asbestos exposed job history and $4.5 \mu \mathrm{m}$ in unexposed subjects; median diameter $0.20 \mu \mathrm{m}$ in those with an asbestos exposed job history and $0 \cdot 10$ $\mu \mathrm{m}$ in those who were unexposed; median aspect ratio $26: 1$ in those with an asbestos exposed job history and 50:1 in those without a history of exposure (all NS)).

Tremolite ( $n=36$ fibres in 18 subjects) was seen both in those with and without exposure (concentration difference NS, tables 1 and 2), and included both cleavage fragments meeting the fibre definition of the study and fibres of greater length and aspect ratio (asbestiform). As in previous work these were not separated. Tremolite aspect ratio varied widely, with a geometric mean within subject aspect ratio greater than $20: 1$ in five cases; greater than 10:1 in seven cases; between 5:1 and 10:1 in four cases; and less than 5:1 in only three cases. Tremolite geometric mean within subject fibre length varied from $3.2 \mu \mathrm{m}$ to $15.3 \mu \mathrm{m}$. Tremolite geometric mean within subject fibre diameter was $0.5 \mu \mathrm{m}$ or less in eight cases, including all five with an aspect ratio greater than $20: 1$, and more than $0.5 \mu \mathrm{m}$ in 10. Only eight tremolite fibres in total were identified in the lungs of four subjects with an asbestos exposed job history (33\%), and all were short (median between subject length $5 \cdot 7 \mu \mathrm{m}$ ), especially thick (median diameter $0.95 \mu \mathrm{m}$ ) cleavage fragments with low aspect ratio (median 6:1). Forty seven per cent of the non-asbestos exposed subjects had a lung tremolite content ( $78 \%$ of all tremolite fibres), with median between subject length $5.3 \mu \mathrm{m}$, diameter $0.50 \mu \mathrm{m} \quad(\mathrm{p}=0.08 \quad v$ asbestos exposed job history), and aspect ratio 7:1 (NS). The highest aspect ratio ( $>20: 1)$ tremolite was always identified in the lungs of metal exposed and silica exposed workers without any history of exposure to asbestos, including the commonly associated chrysotile. These high aspect ratio tremolite fibres (five of 18; median length $10.0 \mu \mathrm{m}$; median width 0.30 $\mu \mathrm{m}$; median aspect ratio $25: 1$ ) thus may have come either from natural sources or from other industrial materials contaminated with tremolite, such as talc or vermiculite.

\section{Discussion}

Lung asbestos content is considered to be the lung asbestos retained dose at the time the lung tissue was obtained. Lung burden is, in theory, a reflection of the combined effects of both the temporal pattern of exposure and the body's retention function to absorb, metabolise, and clear environmental agents. ${ }^{1}$ As such lung burden is an internal dose marker ${ }^{13}$ and should be referred to as lung retained dose or lung retained fibre. For this variable, the theoretical factors of interest are thus exposure over time, intensity of exposure at each time, deposition, translocation, and mucociliary clearance and/or fibre dissolution. In this study, the primary question of interest was whether and how lung retained asbestos fibre is associated with four estimates of asbestos exposure obtained from job history interviews.

The study shows an incremental relation between geometric mean retained lung asbestos fibre and job history derived exposure indices in a selected group of subjects. The confidence of industrial hygienists in rating job histories was also taken into account by the reliability index. All these variables and exposure duration in years had predictive value for individual total lung fibre content in the full group of 42 subjects with ever or never smoking history and for 40 subjects with more detailed smoking history (smoked-years). The distribution of lung asbestos fibre content overlapped considerably among lower exposure index subgroups but clearly delineated the extensive exposure subgroup, regardless of which of the four job history derived variables was used to delineate exposure. Lung fibre content, at least for values exceeding $0.5 \mathrm{f} / \mu \mathrm{g}$ dry lung (fibres longer than $3 \mu \mathrm{m}$; aspect ratio $>3: 1$ ), is thus a robust predictor of exposure with our laboratory methods. 
In fact, with current assumptions for the meaning of individual values of lung asbestos fibre content in our laboratory, six of the exposed subjects, listed in table 3, would have been considered to have occupational (greater than $0.5 \mathrm{f} / \mu \mathrm{g}$ ) asbestos exposure and six would not. Of these, the five with the highest lung content had positive exposure histories and the sixth probably should have had (acetylene welder in a metals processing facility). The seven subjects with positive exposure histories and lower lung content are included in table 4. The first of these, an electrical worker, had a borderline lung content that approached our cutoff of $0.5 \mathrm{f} / \mu \mathrm{g}$ for occupational exposure. The remaining six subjects with positive exposure histories had low lung content that we would interpret as negative for occupational asbestos exposure, but all but two had a very low concentration of exposure index as evaluated by industrial hygiene. Also, two of the three men with an asbestos exposed job history with no detectable lung fibre content had a history of exposure to low concentrations of chrysotile only, and these negative values may reflect clearance. Of course, as one of us has pointed out elsewhere, ${ }^{6}$ a single negative analysis should not be used to exclude significant exposure in the individual case, due to technical factors such as adjacent site variation in lung fibre analysis. ${ }^{7} \mathrm{~A}$ full discussion of the dangers in overinterpretation of lung fibre data in individual analysis is provided in a review by Baker, ${ }^{19}$ although the applicability of the technique to assessment of exposure and of attributability of asbestos related disease such as mesothelioma in epidemiological studies has been well demonstrated in this and other work. ${ }^{8-10}$

There were several sources of potential bias in this study. In the large Montréal study ${ }^{14-17}$ from which subjects were drawn, all interviewed cases were men aged 35-70 with cancer at a wide variety of sites. Patients with cancer and in hospital may not be representative of a general population of workers, although the larger study population (over 1500 men) has been shown to be comparable with Montréal residents of the same age and sex. ${ }^{14-17}$ Further, we know that asbestos exposed workers drawn from necropsy populations are not representative of the working populations from which they come. This has been shown among chrysotile miners and millers in Quebec, who have a four to fivefold increased necropsy rate for cases with mesothelioma, lung cancer, and asbestosis. ${ }^{20}$ Necropsy selection bias, whether recognised or not, is always a factor in studies of lung asbestos fibre content, as necropsies may be performed because of work histories. Inclusion of lung tissue accession from patients undergoing pneumonectomy may have led to some diminution of this bias in the total series from which cases could be drawn. The largest bias, of course, was the selection of subjects having specific exposure histories as ascertained by job history. We could expect to find a correlation between job history and lung content and to find discriminatory power between groups, or at least between those exposed and those unexposed, due to the selection criteria. This was in fact the hypothesis we were testing: that lung fibre content would indeed correspond to prospectively ascertained exposure histories, and our findings bear this out with the limitations discussed here.

Geometric mean values for fibre concentration in this study for the entire group of 42 subjects do not differ significantly from those in the general population. Thus it is reasonable to conclude that our groups not exposed to asbestos are not as a whole different from our general male worker population, even though the sample is highly selective in the ways mentioned. The finding of a significant relation of all relevant asbestos exposure variables to lung content thus confirms the utility of the procedure for the assessment of group exposures and for individual positive values, despite its many theoretical limitations. ${ }^{419}$ The results, in terms of individual sentinel values, are, however, difficult to compare with those of other laboratories because methods in this area are not standardised, particularly with relation to fibre lengths that are included and excluded. ${ }^{421}$ Further, the overlap in descriptive values for the six subjects having low level exposure with the subjects putatively without asbestos exposure indicates a failure of the technique to discriminate all cases with any exposure to asbestos, although these exposures were in fact minimal. It is reasonable to assume that of the approximately $12 \%$ of men exposed to asbestos in the larger study base of Siemiatycki et $a{ }^{15-17}$ those with high level exposure by any of the criteria described could have been identified in most instances by lung tissue analysis, and that some additional subjects (such as the welder in a metals facility in table 3) could be identified as having had exposure even when occupational history did not trigger exposure recognition. It seems as well that the three categorical exposure indices assigned prospectively by the expert group of Siemiatycki and Gérin are better predictors, both individually and together, for lung asbestos retained dose than is simple duration of exposure. This is not surprising given that the combination of rater confidence, frequency, and concentration of exposure may be more reflective of cumulative exposure. This conclusion is based, however, on few subjects. Also, duration of exposure was significantly correlated with lung fibre content, and may be easier to ascertain when expert opinion as to the other variables is not available.

Regression modelling was distinguished in this study by the use of different exposure variables. Exposure duration was measured as total job-exposed years (omitting gaps in such jobs) to asbestos and the exposure indices were coded on three point ordinal scales. Although each exposure variable measured different dimensions of job exposure, these exposure variables were, by nature, correlated due to the common distinction between subjects with and without asbestos job history exposure. When the four exposure variables 
were compared in the full models, exposure concentration index (intensity of exposure in the workplace) was the best and duration of exposure the poorest predictor of lung asbestos content, although all were significant in the model including age at necropsy or pneumonectomy and smoking. The stepwise procedure yielded a two term model, however, based solely on exposure concentration index and a negative effect of age. This explained a higher proportion of the variance of total lung asbestos content than did the three term full models with exposure indices, other than that with the exposure concentration index, and so reinforces the impression that in this study exposure concentration is the most important predictor of lung asbestos content.

The results of regression analyses also show a significant negative association between age at the time of necropsy or pneumonectomy and lung asbestos retained dose. This factor may be related to asbestos clearance from the lung, as in the study of chrysotile and tremolite fibres in the lungs of chrysotile miners, millers, and textile workers by Sébastien et al. ${ }^{8}$ In that study, the authors found it essential to correct for cessation period, or time between last exposure and death, to correct for clearance. When this correction was performed, there was excellent correspondence between historical industrial hygiene workplace measurements of exposure to fibres and lung asbestos content. Studies that do not take clearance time into account may have misleading conclusions, at least where chrysotile and tremolite are concerned. This may not be as strong a factor in relation to commercial amphiboles, but a similar detailed analysis where good industrial hygiene measurements are available has not been provided to date. In this study we had industrial hygiene data on duration of exposure, surrogates for exposure concentration and frequency, and historical data on time between last exposure and lung tissue accession, whether by necropsy or pneumonectomy. These data are based on few cases, however, and the surrogate measurements are based on expert judgment rather than derived directly from historical exposure measurements.

We explored the issue of fibre clearance further by attempting to correlate the $\log$ of total asbestos content with cessation period (time between end of exposure of the most recent asbestos related job and death or pneumonectomy). Cessation period has been shown to be associated with lung chrysotile and tremolite content in chrysotile miners and millers and in chrysotile textile workers. ${ }^{8} \mathrm{We}$ also attempted correlation with the log of total asbestos and time from initial exposure to tissue accession. In neither instance was there any correlation with lung content (for cessation interval $r=-0.21, p=0.51$; for time since first exposure $r=0.13, p=0.68$ ). The short nature of some jobs, their mixed nature in terms of fibre type and exposure intensity, and the few cases do not allow us to draw any direct conclusion from these findings. It remains possible that, in this small and heterogeneous study population, age, in fact, gives a better description of fibre clearance or dissolution than the more precise categories such as cessation period found so useful in larger, more homogeneous populations such as chrysotile miners and millers.

Roggli et $a l^{11}$ found a significant correlation between the grade of asbestosis and smoking history in pack-years but no correlation between uncoated fibre content of lung tissue and pack-years of smoking. The present study is not directly comparable, as only one man had asbestosis (table 3 ). The proportion of smokers (of any kind of tobacco) among those exposed was $100 \%$, and one comparison subgroup of six subjects was specifically chosen to include smokers without significant occupational exposure history to any particulate matter. ${ }^{23}$ Another subgroup of six subjects was chosen as non-smokers without a history of such exposure. Thus conclusions on smoking and fibre content, whether positive or negative, must be performed with caution. None the less the implicit assumption of Roggli et $a l,{ }^{4}$ that smoking interferes with dust clearance mechanisms in the lung, could not be supported in our study. Regression analyses run with both ever or never smoked state and with smoked-years showed no effect of smoking on lung fibre content. An intriguing finding was the excess of chrysotile and tremolite (tables 1 and 2) in the subgroup of smokers without professional exposure to particulates, but small numbers make this difficult to interpret and statistically insignificant. More expected was the statistically significant deficit in amosite and total commercial amphiboles in the small subgroup selected for smoking state and lack of exposure. This is more consistent with the hypothesis of Roggli et al. ${ }^{11}$ If the chrysotile and tremolite found in the lungs of the smoking subgroup were derived from natural or non-professional environmental sources the hypothesis would be confirmed, but we cannot be sure of this, even though the detailed exposure histories showed no jobs associated with exposure to chrysotile, talc, vermiculite, or other materials reported to be associated in professional exposures with tremolite. Overall, subjects with no asbestos related work history but positive smoking history had a lung asbestos content intermediate between subjects with neither smoking history nor asbestos exposure history and smoking subjects with a history of asbestos exposure.

It is a noteworthy aspect of this study that sources of information for the main variables of interest are mutually independent: job histories and exposure indices were compiled before lung tissue analysis, and the procedure of fibre analysis was entirely blind to job and smoking history. The prospective nature of data collection is by contrast with studies relating lung fibre content to job related diseases where the identification and/or coding of job exposures was done retrospectively. ${ }^{1112}$

Although inferences are limited by the few subjects, the present study shows interpretable concordance between job history 
based exposure indices and lung asbestos fibre retained dose. This lends support to the use of such carefully determined exposure indices in occupational epidemiological studies. Future research relating to lung asbestos and other mineral particle retained dose should more adequately consider the potential for confounding by smoking state and continue to explore inter-relations among chronological factors such as duration of exposure, frequency of exposure, and cessation interval.

This work was supported by a grant from the National Cancer 812761 between the United States Environmental Protection Agency and the University of Pittsburgh. No official endorsement is implied.

1 Characterizing the workplace environment. In: Checkoway $\mathrm{H}$, Pearce NE, Crawford-Brown DJ, eds. Research methods in occupational epidemiology. New York: Oxford University Press, 1989:18-45.

2 Dufresne A, Perreault G, Case BW, Fraser R. A protocol for lung particulate analysis by transmission electron microscopy. In: McCallum I, Dodgson J, eds. Seventh international symposium on inhaled particles. London: international symposium on inhaled

3 Case BW, Dufresne A, Fraser R, Siemiatycki J, Perrault G, Takahashi K. Decoding occupational history from total particulate analysis: concordance between physicochemical analysis and occupational histories. In: McCallum R, Dodgson J, eds. Seventh international symposium on inhaled particles. London: Pergamon Press, 1984 (in press).

4 Case BW. Lung fibre content as a marker of low-level asbestos exposure. In: Gibbs G, Dunnigan J, Kido M, Higashi $\mathrm{T}$, eds. Health risks from exposure to mineral fibres: an international perspective. North York, Ontario: Captus University Press, 1993:326-33.

5 Case BW, Sébastien P. Environmental and occupational exposures to chrysotile asbestos: a comparative microanalytic study. Arch Environ Health 1987;42:185-91.

6 Case BW. Biological indicators of chrysotile exposure. In: Gibbs GW, Valic F, Browne K, eds. Health risks associGibbs GW, Valic F, Browne $\mathrm{K}$, eds. Health risks associated with chrysotile asbestos: a report on a workshop held in
fersey, Channel Islands. Ann Occup Hyg 1994 (in press).
7 Churg A, Wood P. Observations on the distribution of asbestos fibres in human lungs. Environ Res 1983; asbestos fib

8 Sébastien $\mathrm{P}$, McDonald JC, McDonald AD, Case B, Harley R. Respiratory cancer in chrysotile textile and mining industries: exposure inferences from lung analysis. $\mathrm{Br}$ F Ind Med 1989;46:180-7.

9 McDonald JC, Case BW, Enterline PE, et al. Lung dust analysis in the assessment of past exposure of manmade mineral fibre workers. Ann Occup Hyg 1990;34: 427-41

10 McDonald JC, Armstrong B, Case BW, et al. Mesothelioma and asbestos fiber type: evidence from lung tissue analyses. Cancer 1989;63:1544-7.

11 Roggli VL, Pratt PC, Brody AR. Asbestos content of lung tissue in asbestos associated diseases: a study of 110 cases. Br f Ind Med 1986;43:18-28.

12 Tuomi T, Huuskonen MS, Tammilehto L, Vanhala E, Virtamo M. Occupational exposure to asbestos as evaluated from work histories and analysis of lung tissues ated from work histories and analysis of lung tissues
from patients with mesothelioma. Br $\mathcal{f}$ Ind Med 1991; from patients

13 Hulka BS, Wilcosky TW. Biological markers of disease. Arch Environ Health 1987;43:83-9.

14 Gérin M, Siemiatycki J, Kemper H, Begin D. Obtaining occupational exposure histories in epidemiologic casecontrol studies. $₹$ Occup Med 1985;27:420-6.

15 Siemiatycki J, Day NE, Fabry J, Cooper JA. Discovering carcinogens in the occupational environment: a novel epidemiologic approach. If Natl Cancer Inst 1981;66: 217-25.

16 Siemiatycki J, Richardson L, Gérin M, et al. Associations between several sites of cancer and nine organic dusts: results from an hypothesis-generating case-control study in Montréal, 1979-1983. Am f Epidemiol 1986;123: in Montre.

17 Siemiatycki J, Wacholder S, Richardson L, Dewar R Gérin $M$. Discovering carcinogens in the occupational environment: methods of data collection and analysis of a large case-referent monitoring system. Scand 7 Work Environ Health 1987;13:486-92.

18 Goldberg MS, Siemiatycki J, Gérin M. Inter-rater agreement in assessing occupational exposure in a case-control study. $\mathrm{Br} \mathcal{F}$ Ind Med 1986;43:667-76.

19 Baker $D$. Limitations in drawing etiologic inferences based on measurement of asbestos fibers from lung tissue. $A n n$ NY Acad Sci 1991;643:61-70.

20 Case BW. Asbestos: an autopsy series, and epidemiology [abstract]. Canadian Congress on Laboratory Medicine 1993;44:87.

21 Weill HW, Abraham J, Balmes J, et al. Health effects of tremolite. Am Rev Respir Dis 1990;142:1453-8. 